\title{
A NEW ROUTE FOR THE SYNTHESIS OF ALKALI POLYPHOSPHATE FROM ECONOMICAL STARTING MATERIALS: PART II-INFLUENCE OF REACTION CONDITIONS
}

\author{
Doan Pham Minh, ${ }^{1}$ Ange Nzihou, ${ }^{1}$ Patrick Sharrock, ${ }^{2}$ \\ and Jocelyn Ramaroson ${ }^{1}$ \\ ${ }^{1}$ Universite' de Toulouse, Mines Albi, CNRS, Centre RAPSODEE, Albi, France ${ }^{2} I U T$ de \\ Castres, Castres, France
}

GRAPHICAL ABSTRACT

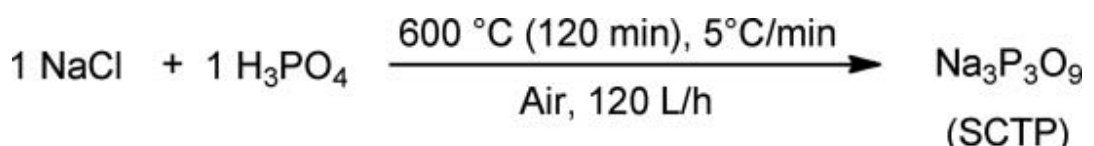

$\mathrm{Cl}^{-}$elimination: $98 \%$; selectivity for SCTP: $94 \%$

\begin{abstract}
Direct synthesis of sodium cyclotriphosphate, $\mathrm{Na}_{3} \mathrm{P}_{3} \mathrm{O}_{9}(\mathrm{SCTP})$, from sodium chloride and orthophosphoric acid as economical starting materials was investigated. Reaction conditions including the heating rate, reaction plateau time, air flow rate, and Na/P molar ratio were found to be key parameters for the elimination of chloride and for the selectivity in SCTP. High yields in SCTP (94-99\%) were obtained. The results are very interesting with respect to a potential industrial application for the synthesis of SCTP from point of view of the low cost of the starting materials.
\end{abstract}

Keywords Sodium polyphosphate; sodium cyclotriphosphate; sodium chloride; orthophosphoric acid; thermal synthesis

\section{INTRODUCTION}

Condensed phosphates are phosphate anions having one or several P-O-P bonds, which are formed by hydrolysis and dehydration reactions of orthophosphate anion under thermal conditions. ${ }^{1,2}$ Their formation and structure depend on several parameters of synthesis: reaction temperature, heating rate, reaction time, cooling rate of melts, phosphorus/metal molar ratio, source of orthophosphate, etc. ${ }^{3,4}$

Sodium cyclotriphosphate, $\mathrm{Na}_{3} \mathrm{P}_{3} \mathrm{O}_{9}$ (SCTP), is used in different applications like detergency, food chemistry, water treatment, etc. ${ }^{1,5-8}$ Moreover, SCTP is the starting material

The authors thank colleagues at RAPSODEE (Research Centre in Albi on Particulate Solids, Energy and the Environment) for their technical help.

Address correspondence to Doan Pham Minh, Université de Toulouse, Mines Albi, CNRS, Centre RAPSODEE, Campus Jarlard F-81013 Albi cedex 09, France. E-mail: doan.phamminh@mines-albi.fr 
for the preparation of all other metal cyclotriphosphates such as $\mathrm{K}_{3} \mathrm{P}_{3} \mathrm{O}_{9}, \mathrm{Ag}_{3} \mathrm{P}_{3} \mathrm{O}_{9} \cdot \mathrm{H}_{2} \mathrm{O}$, $\mathrm{Mn}_{3}\left(\mathrm{P}_{3} \mathrm{O}_{9}\right)_{2} \cdot 10 \mathrm{H}_{2} \mathrm{O}, \mathrm{Ca}_{3}\left(\mathrm{P}_{3} \mathrm{O}_{9}\right)_{2} \cdot 10 \mathrm{H}_{2} \mathrm{O}, \mathrm{Ba}_{3}\left(\mathrm{P}_{3} \mathrm{O}_{9}\right)_{2} \cdot 4 \mathrm{H}_{2} \mathrm{O}, \mathrm{Tl}_{3} \mathrm{P}_{3} \mathrm{O}_{9}, \mathrm{Rb}_{3} \mathrm{P}_{3} \mathrm{O}_{9} \cdot \mathrm{H}_{2} \mathrm{O}$, $\mathrm{Na}_{2} \mathrm{LiP}_{3} \mathrm{O}_{9}, \mathrm{Na}_{2} \mathrm{CsP}_{3} \mathrm{O}_{9} \cdot 2 \mathrm{H}_{2} \mathrm{O}, \mathrm{Ln}(\mathrm{Bi}) \mathrm{Na}_{3} \mathrm{P}_{3} \mathrm{O}_{9} \cdot 9 \mathrm{H}_{2} \mathrm{O}$, etc. ${ }^{9}$ The actual competing industrial process for the synthesis of SCTP was developed by Thilo and Grunze in 1955. ${ }^{10-12}$ Sodium dihydrogen orthophosphate is heated to about $550{ }^{\circ} \mathrm{C}$ for $5 \mathrm{~h}$ and cooled to room temperature. Pure SCTP is then obtained by a purification step using recrystallization technique. Considering the industrial synthesis of sodium dihydrogen orthophosphate from sodium hydroxide and orthophosphoric acid, we have the following scheme for SCTP industrial synthesis process:

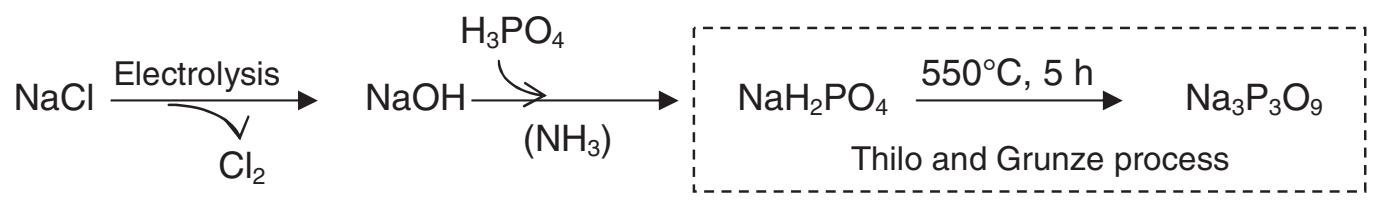

Our previous work shows that SCTP could be obtained from the direct reaction of sodium chloride and orthophosphoric acid at reaction temperature lower than $628^{\circ} \mathrm{C} .{ }^{13}$ The present study investigates the influence of different synthesis parameters on the conversion of the initial reactants and the selectivity in forming SCTP. In comparison with the Thilo and Grunze process, the proposed process is more economical and ecological as it avoids the electrolysis and neutralization steps.

\section{RESULTS AND DISCUSSION}

\section{Influence of the Heating Rate}

When the powder of sodium chloride is set in contact with $85 \mathrm{wt} \%$ orthophosphoric acid at high temperature, hydrochloric acid is formed and leaves the reaction mixture as vapor. The general reaction between sodium chloride and orthophosphoric acid can be described by the following equation:

$$
(85 \mathrm{wt} \%) \mathrm{H}_{3} \mathrm{PO}_{4} \text { (liquid) }+\mathrm{NaCl}(\text { solid }) \stackrel{\mathrm{T}}{\rightarrow} \mathrm{Na}_{\mathrm{a}} \mathrm{H}_{\mathrm{b}} \mathrm{P}_{\mathrm{c}} \mathrm{O}_{\mathrm{d}} \text { (solid) }+\mathrm{HCl}(\text { gas })+\mathrm{H}_{2} \mathrm{O}(\text { gas })
$$

where $\mathrm{Na}_{\mathrm{a}} \mathrm{H}_{\mathrm{b}} \mathrm{P}_{\mathrm{c}} \mathrm{O}_{\mathrm{d}}$ is the solid product of the reaction.

As for all thermal processes, the heating rate was first investigated at different reaction temperatures from 300 to $600{ }^{\circ} \mathrm{C}$. The influence of the heating rate on the distribution of chloride and phosphorus-containing species in the solid products, as obtained from ionic chromatography analysis, is shown in Table 1.

No influence of the heating rate on the distribution of chloride, orthophosphate, and pyrophosphate was observed. However, the heating rate had some effects on the formation of cyclotriphosphate anion $\left(\mathrm{P}_{3} \mathrm{O}_{9}{ }^{3-}\right)$ at 300 and at $400{ }^{\circ} \mathrm{C}$. A slight influence of the heating rate was recognized at $300{ }^{\circ} \mathrm{C}$ with higher selectivity for $\mathrm{P}_{3} \mathrm{O}_{9}{ }^{3-}$ at 2 and $5{ }^{\circ} \mathrm{C} / \mathrm{min}$ than at 10 and $20^{\circ} \mathrm{C} / \mathrm{min}$. In fact, the time to reach the reaction temperature of $300{ }^{\circ} \mathrm{C}$ at heating rates of $10^{\circ} \mathrm{C} / \mathrm{min}$ and $20^{\circ} \mathrm{C} / \mathrm{min}$ starting from ambient temperature was only $28 \mathrm{~min}$ and 14 min, respectively. These heating times could be too short for the transformation of initial orthophosphate species and intermediates into $\mathrm{P}_{3} \mathrm{O}_{9}{ }^{3-}$, which explains the low selectivity for $\mathrm{P}_{3} \mathrm{O}_{9}{ }^{3-}(4 \%)$. On the other hand, the heating rates of $2{ }^{\circ} \mathrm{C} / \mathrm{min}$ and $5{ }^{\circ} \mathrm{C} / \mathrm{min}$ required a 
Table 1 Influence of the heating rate on the distribution of chloride and phosphorus species in the final solid product. $\mathrm{S}_{\mathrm{P} 3 \mathrm{O} 9}$ : selectivity with respect to $\mathrm{P}_{3} \mathrm{O}_{9}{ }^{3-}$ anion. Reaction conditions: initial quantity of $\mathrm{NaCl}$ and $85 \mathrm{wt} \%$ orthophosphoric acid: $87.5 \mathrm{mmol}$, reaction plateau time: $30 \mathrm{~min}$, air flow rate: $120 \mathrm{~L} / \mathrm{h}$

\begin{tabular}{|c|c|c|c|c|c|c|}
\hline $\begin{array}{l}T \\
\left({ }^{\circ} \mathrm{C}\right)\end{array}$ & $\begin{array}{l}\text { Heating rate } \\
\left({ }^{\circ} \mathrm{C} / \mathrm{min}\right)\end{array}$ & $\begin{array}{c}\mathrm{Cl}^{-} \\
(\mathrm{mmol})\end{array}$ & $\begin{array}{c}\mathrm{PO}_{4}^{3-} \\
(\mathrm{mmol})\end{array}$ & $\begin{array}{l}\mathrm{P}_{2} \mathrm{O}_{7}^{4-} \\
(\mathrm{mmol})\end{array}$ & $\begin{array}{l}\mathrm{P}_{3} \mathrm{O}_{9}^{3-} \\
(\mathrm{mmol})\end{array}$ & $\begin{array}{c}\mathrm{S}_{\mathrm{P} 3 \mathrm{O} 9} \\
(\%)\end{array}$ \\
\hline 300 & 2 & 26 & 27 & 8 & 3 & 10 \\
\hline 300 & 5 & 23 & 27 & 7 & 4 & 15 \\
\hline 300 & 10 & 24 & 17 & 9 & 1 & 4 \\
\hline 300 & 20 & 23 & 18 & 9 & 1 & 4 \\
\hline 400 & 2 & 7 & 2 & 1 & 22 & 76 \\
\hline 400 & 5 & 10 & 1 & 1 & 23 & 79 \\
\hline 400 & 10 & 11 & 2 & 1 & 23 & 78 \\
\hline 400 & 20 & 12 & 3 & 2 & 17 & 60 \\
\hline 500 & 2 & 8 & 1 & trace & 23 & 79 \\
\hline 500 & 5 & 9 & trace & 2 & 23 & 80 \\
\hline 500 & 10 & 9 & 2 & 1 & 23 & 79 \\
\hline 500 & 20 & 9 & 1 & 1 & 23 & 79 \\
\hline 600 & 5 & 3 & 0 & trace & 24 & 84 \\
\hline
\end{tabular}

time of $140 \mathrm{~min}$ and $70 \mathrm{~min}$, respectively, to reach $300{ }^{\circ} \mathrm{C}$. So orthophosphate species and intermediates had more time to be converted into $\mathrm{P}_{3} \mathrm{O}_{9}{ }^{3-}$.

At $400{ }^{\circ} \mathrm{C}$, chloride elimination was more effective at $2{ }^{\circ} \mathrm{C} / \mathrm{min}$ than at other heating rates. Similar selectivity for $\mathrm{P}_{3} \mathrm{O}_{9}{ }^{3-}$ in the range of 76-79\% was observed for the heating rate range $2-10{ }^{\circ} \mathrm{C} / \mathrm{min}$. A smaller selectivity of $60 \%$ for $\mathrm{P}_{3} \mathrm{O}_{9}{ }^{3-}$ was observed at heating rate of $20^{\circ} \mathrm{C} / \mathrm{min}$, probably due to the shorter time at this heating rate to reach the reaction temperature, as explained above for the reaction temperature of $300{ }^{\circ} \mathrm{C}$.

At $500{ }^{\circ} \mathrm{C}$, the results were similar for all heating rates with a constant selectivity for $\mathrm{P}_{3} \mathrm{O}_{9}{ }^{3-}$ of $80 \%$. Thus, the reaction at $600{ }^{\circ} \mathrm{C}$ was carried out only at the heating rate of $5{ }^{\circ} \mathrm{C} / \mathrm{min}$. At $600{ }^{\circ} \mathrm{C}$, the elimination of chloride and the selectivity in $\mathrm{P}_{3} \mathrm{O}_{9}{ }^{3-}$ were higher than those achieved at 300,400 , or $500{ }^{\circ} \mathrm{C}$ as observed in previous investigations. ${ }^{13}$

In conclusion, the heating rate influenced mostly the selectivity for $\mathrm{P}_{3} \mathrm{O}_{9}{ }^{3-}$ anion. At three investigated temperatures of 300,400 , and $500{ }^{\circ} \mathrm{C}$, the heating rate of $5{ }^{\circ} \mathrm{C} / \mathrm{min}$ was the most favorable for the formation of $\mathrm{P}_{3} \mathrm{O}_{9}{ }^{3-}$.

\section{Influence of the Air Flow Rate}

The air circulation permits to remove the vapor of water and hydrochloric acid during the reaction and, therefore, influences the performance of the process. Thus, the synthesis was carried out at $350{ }^{\circ} \mathrm{C}$ with an air flow rate varying from 30 to $240 \mathrm{~L} / \mathrm{h}$. The reaction temperature of $350^{\circ} \mathrm{C}$ was chosen to better observe the effect of the air flow rate. The result of this study is presented in Table 2.

At the reaction temperature of $350^{\circ} \mathrm{C}$, no effect of the air flow rate on the elimination of chloride was observed. On the other hand, orthophosphate species and pyrophosphate decreased with increasing air flow rate. In fact, the increase of air flow rate leads to a more effective removal of the gaseous products and so the dehydration of orthophosphate species, pyrophosphate, and eventually other intermediates takes place more readily. At the same time, the selectivity for $\mathrm{P}_{3} \mathrm{O}_{9}{ }^{3-}$ increases from 39 to $77 \%$ when the air flow rate is increased 
Table 2 Influence of the air flow rate on the distribution of chloride and phosphorus species in the final solid product. $\mathrm{S}_{\mathrm{P} 309}$ : selectivity for $\mathrm{P}_{3} \mathrm{O}_{9}{ }^{3-}$ anion. Reaction conditions: temperature: $350{ }^{\circ} \mathrm{C}$, initial $\mathrm{NaCl}$ and $85 \mathrm{wt} \%$ orthophosphoric acid: $87.5 \mathrm{mmol}$, reaction plateau time: $30 \mathrm{~min}$

\begin{tabular}{lccccc}
\hline Air flow rate $(\mathrm{L} / \mathrm{h})$ & $\mathrm{Cl}^{-}(\mathrm{mmol})$ & $\mathrm{PO}_{4}{ }^{3-}(\mathrm{mmol})$ & $\mathrm{P}_{2} \mathrm{O}_{7}{ }^{4-}(\mathrm{mmol})$ & $\mathrm{P}_{3} \mathrm{O}_{9}{ }^{3-}(\mathrm{mmol})$ & $\mathrm{S}_{\mathrm{P} 3 \mathrm{O} 9}(\%)$ \\
\hline 30 & 10 & 12 & 3 & 11 & 39 \\
60 & 10 & 8 & 3 & 22 & 77 \\
120 & 10 & 4 & 2 & 23 & 79 \\
240 & 10 & 1 & 1 & 23 & 80 \\
\hline
\end{tabular}

from 30 to $60 \mathrm{~L} / \mathrm{h}$. In the range $60-240 \mathrm{~L} / \mathrm{h}$, the selectivity for $\mathrm{P}_{3} \mathrm{O}_{9}{ }^{3-}$ increases only slightly from 77 to $80 \%$. This study suggests that the air flow rate should be in range $60-120 \mathrm{~L} / \mathrm{h}$. A higher air flow rate is not recommended because of the higher energy consumption in order to keep the reaction temperature unchanged.

\section{Influence of the Reaction Plateau Time}

The effect of the reaction plateau time on the elimination of chloride and the distribution of the phosphorus-containing species is shown in Table 3.

Despite the increase of the reaction plateau time up to $1440 \mathrm{~min}$, the content of chloride in the final product was only slightly reduced. Alternatively, the reaction temperature of $300{ }^{\circ} \mathrm{C}$ was not sufficient for a total elimination of chloride during a long reaction time $(24 \mathrm{~h})$. On the other hand, the reaction plateau time influenced strongly the distribution of phosphorus-containing species and the selectivity for the $\mathrm{P}_{3} \mathrm{O}_{9}{ }^{3-}$ anion. Orthophosphate species nearly disappear after $120 \mathrm{~min}$ of reaction time. Pyrophosphate, formed as the first intermediate at the beginning of the reaction also disappears after $120 \mathrm{~min}$. The portion of $\mathrm{P}_{3} \mathrm{O}_{9}{ }^{3-}$ anion strongly increases between 30 and $480 \mathrm{~min}$ of reaction plateau time. The highest selectivity for $\mathrm{P}_{3} \mathrm{O}_{9}{ }^{3-}$ was found at $88 \%$ after allowing the reaction to proceed for $480 \mathrm{~min}$. However, a longer reaction time $(1440 \mathrm{~min})$ resulted in a decrease of the selectivity for $\mathrm{P}_{3} \mathrm{O}_{9}{ }^{3-}$, which is probably due to the transformation of $\mathrm{P}_{3} \mathrm{O}_{9}{ }^{3-}$ into other products. So the most favorable reaction plateau time was found to be $120 \mathrm{~min}$ for the elimination of chloride and for the best selectivity with respect to the $\mathrm{P}_{3} \mathrm{O}_{9}{ }^{3-}$ anion.

Table 3 Influence of the reaction plateau time on the distribution of chloride and phosphorus species in the final solid product. $\mathrm{S}_{\mathrm{P} 3 \mathrm{O} 9}$ : selectivity for $\mathrm{P}_{3} \mathrm{O}_{9}{ }^{3-}$ anion. Reaction conditions: initial quantity of $\mathrm{NaCl}$ and $85 \mathrm{wt} \%$ orthophosphoric acid: $87.5 \mathrm{mmol}$, air flow rate: $120 \mathrm{~L} / \mathrm{h}$, reaction temperature: $300{ }^{\circ} \mathrm{C}$

\begin{tabular}{lccccc}
\hline $\begin{array}{l}\text { Reaction plateau } \\
\text { time (min) }\end{array}$ & $\begin{array}{c}\mathrm{Cl}^{-} \\
(\mathrm{mmol})\end{array}$ & $\begin{array}{c}\mathrm{PO}_{4}{ }^{3-} \\
(\mathrm{mmol})\end{array}$ & $\begin{array}{c}\mathrm{P}_{2} \mathrm{O}_{7}{ }^{4-} \\
(\mathrm{mmol})\end{array}$ & $\begin{array}{c}\mathrm{P}_{3} \mathrm{O}_{9}{ }^{3-} \\
(\mathrm{mmol})\end{array}$ & $\begin{array}{c}\mathrm{S}_{\mathrm{P} 3 \mathrm{O} 9} \\
(\%)\end{array}$ \\
\hline 5 & 23 & 28 & 8 & 4 & 15 \\
30 & 23 & 27 & 7 & 4 & 15 \\
120 & 21 & 4 & 2 & 23 & 79 \\
240 & 17 & 1 & 1 & 23 & 79 \\
480 & 15 & 1 & trace & 26 & 68 \\
1440 & 15 & 0 & trace & 19 & 94 \\
$120^{*}$ & 1 & 0 & 0 & 28 & 9 \\
\hline
\end{tabular}

${ }^{*}$ Reaction temperature: $600{ }^{\circ} \mathrm{C}$; air flow rate: $120 \mathrm{~L} / \mathrm{h}$, and reaction plateau time: $120 \mathrm{~min}$. 
Table 4 Influence of the $\mathrm{Na} / \mathrm{P}$ molar ratio on the distribution of chloride and phosphorus species in the final solid product. $\mathrm{S}_{\mathrm{P} 309}$ : selectivity in $\mathrm{P}_{3} \mathrm{O}_{9}{ }^{3-}$ anion. Reaction conditions: air flow rate: $120 \mathrm{~L} / \mathrm{h}$, reaction plateau time: $30 \mathrm{~min}, \mathrm{H}_{3} \mathrm{PO}_{4}{ }^{(\mathrm{i})}$ : initial quantity of orthophosphoric acid, $\mathrm{NaCl}^{(\mathrm{i})}$ : initial quantity of $\mathrm{NaCl}$

\begin{tabular}{lcccccccr}
\hline $\begin{array}{l}\mathrm{H}_{3} \mathrm{PO}_{4}{ }^{(\mathrm{i})} \\
(\mathrm{mmol})\end{array}$ & $\begin{array}{c}\mathrm{NaCl}^{(\mathrm{i})} \\
(\mathrm{mmol})\end{array}$ & $\begin{array}{c}\mathrm{Na} / \mathrm{P} \\
\text { molar ratio }\end{array}$ & $\begin{array}{c}T \\
\left({ }^{\circ} \mathrm{C}\right)\end{array}$ & $\begin{array}{c}\mathrm{Cl}^{-} \\
(\mathrm{mmol})\end{array}$ & $\begin{array}{c}\mathrm{PO}_{4}{ }^{3-} \\
(\mathrm{mmol})\end{array}$ & $\begin{array}{c}\mathrm{P}_{2} \mathrm{O}_{7}{ }^{4-} \\
(\mathrm{mmol})\end{array}$ & $\begin{array}{c}\mathrm{P}_{3} \mathrm{O}_{9}{ }^{3-} \\
(\mathrm{mmol})\end{array}$ & $\begin{array}{c}\mathrm{S}_{\mathrm{P} 3 \mathrm{O}} \\
(\%)\end{array}$ \\
\hline 87.5 & 175 & $1 / 2$ & 300 & 1 & 12 & 11 & 2 & 7 \\
& & & 400 & trace & 3 & 1 & 2 & 6 \\
87.5 & 87.5 & $1 / 1$ & 300 & 23 & 27 & 7 & 4 & 15 \\
& & & 400 & 10 & 1 & 5 & 23 & 79 \\
175 & 87.5 & $2 / 1$ & 300 & 101 & 5 & 5 & 29 \\
& & & 400 & 86 & 1 & trace & 29 & 99 \\
\hline
\end{tabular}

From the results obtained above, a synthesis was then carried out at the most favorable conditions found for the $\mathrm{Na} / \mathrm{P}$ molar ratio of 1/1: reaction plateau time of $120 \mathrm{~min}$, reaction temperature of $600{ }^{\circ} \mathrm{C}$, heating rate of $5^{\circ} \mathrm{C} / \mathrm{min}$, and an air flow rate of $120 \mathrm{~L} / \mathrm{h}$ (Table 3 ). As expected, the elimination of chloride was nearly total (98\%) and a high selectivity for $\mathrm{P}_{3} \mathrm{O}_{9}{ }^{3-}$ of $94 \%$ was obtained. This was also the best result obtained with the $\mathrm{Na} / \mathrm{P}$ molar ratio of 1/1; the solid thus obtained is labeled Syn1.

\section{Influence of the Na/P Molar Ratio}

This study was carried out at 300 and $400{ }^{\circ} \mathrm{C}$ with $\mathrm{Na} / \mathrm{P}$ molar ratios of $1 / 2,1 / 1$, and $2 / 1$ (Table 4). The result obtained at the molar ratio $\mathrm{Na} / \mathrm{P}=1 / 1$, which was already shown in Table 1, is also included in Table 4 for comparison.

When an excess of orthophosphoric acid was used $(\mathrm{Na} / \mathrm{P}=1 / 2)$, the chloride elimination rate was nearly total even at $300{ }^{\circ} \mathrm{C}$. Orthophosphate species $\left(\mathrm{PO}_{4}{ }^{3-}\right)$ disappear completely and $\mathrm{P}_{2} \mathrm{O}_{7}{ }^{4-}$ and $\mathrm{P}_{3} \mathrm{O}_{9}{ }^{3-}$ anions were found only in small amounts. This means that other intermediates were formed, which were not detected by ionic chromatography. So the excess of orthophosphoric acid is not favorable for the formation of the $\mathrm{P}_{3} \mathrm{O}_{9}{ }^{3-}$ anion.

When an excess of sodium chloride was used $(\mathrm{Na} / \mathrm{P}=2 / 1)$, a great amount of chloride remained in the final product. At $300{ }^{\circ} \mathrm{C}, \mathrm{PO}_{4}{ }^{3-}$ and $\mathrm{P}_{2} \mathrm{O}_{7}{ }^{4-}$ were still present and the selectivity for the $\mathrm{P}_{3} \mathrm{O}_{9}{ }^{3-}$ anion reached only $29 \%$. At $400{ }^{\circ} \mathrm{C}, \mathrm{PO}_{4}{ }^{3-}$ was nearly totally converted into $\mathrm{P}_{3} \mathrm{O}_{9}{ }^{3-}$ anion (99\% of selectivity) and a half of the initial amount of chloride was consumed. The solid product obtained with $99 \%$ of selectivity with respect to the $\mathrm{P}_{3} \mathrm{O}_{9}{ }^{3-}$ anion is labeled Syn2.

In conclusion, an equimolar $\mathrm{Na} / \mathrm{P}$ ratio $(\mathrm{Na} / \mathrm{P}=1 / 1)$ or an excess of sodium chloride $(\mathrm{Na} / \mathrm{P}>1 / 1)$ is required to obtain a high selectivity for $\mathrm{P}_{3} \mathrm{O}_{9}{ }^{3-}$.

\section{Mass Balance}

For all experiments, the mass balance for elemental chlorine, sodium, and phosphorus was established. ICP-AES analysis showed that all initial sodium and phosphorus were found in the final solid product. At the same time, the analysis of the gaseous products trapped in the wash bottle showed the presence of only chlorine in form of hydrochloric acid, which was easily condensed from the gas output of the reactor. The total quantity 
of chlorine in the gaseous and solid products reached in all cases the initial quantity of chlorine in the $\mathrm{NaCl}$ used.

\section{Characterization of the Solid Product}

By varying the reaction conditions, high selectivity for the $\mathrm{P}_{3} \mathrm{O}_{9}{ }^{3-}$ anion up to $99 \%$ was obtained, as showed by ionic chromatography analysis. However, additional characterization is necessary to identify the corresponding product.

Characterization by XRD. All solid products were analyzed by XRD technique. The results show that $\mathrm{P}_{3} \mathrm{O}_{9}{ }^{3-}$ anion is present mainly as $\mathrm{Na}_{3} \mathrm{P}_{3} \mathrm{O}_{9}$ (SCTP), but in some cases small amounts of $\mathrm{Na}_{2} \mathrm{HP}_{3} \mathrm{O}_{9}$ could be detected. The compound $\mathrm{Na}_{2} \mathrm{HP}_{3} \mathrm{O}_{9}$ was only observed when the selectivity for $\mathrm{P}_{3} \mathrm{O}_{9}{ }^{3-}$ was high and the chloride elimination rate was low, resulting in a deficiency of sodium for the formation of SCTP. For example, in Table 3 within the reaction plateau time range from 120 to 480 min $\mathrm{Na}_{2} \mathrm{HP}_{3} \mathrm{O}_{9}$ was present in the solid products because the quantity of sodium (in mmol) liberated from the elimination of chloride was much smaller than the quantity of orthophosphates (in mmol) transformed into $\mathrm{P}_{3} \mathrm{O}_{9}{ }^{3-}$ anion. In addition, the reaction temperature of $300{ }^{\circ} \mathrm{C}$ might also not have been sufficient to remove the last hydrogen atom of $\mathrm{P}_{3} \mathrm{O}_{9}{ }^{3-}$ ring and substitute it by sodium atom. ${ }^{14}$

Figure 1 shows the XRD patterns of the two solid products (Syn1 and Syn2) having the best selectivity for $\mathrm{P}_{3} \mathrm{O}_{9}{ }^{3-}$ for the $\mathrm{Na} / \mathrm{P}$ molar ratio of $1 / 1$ or $2 / 1$ in comparison with that

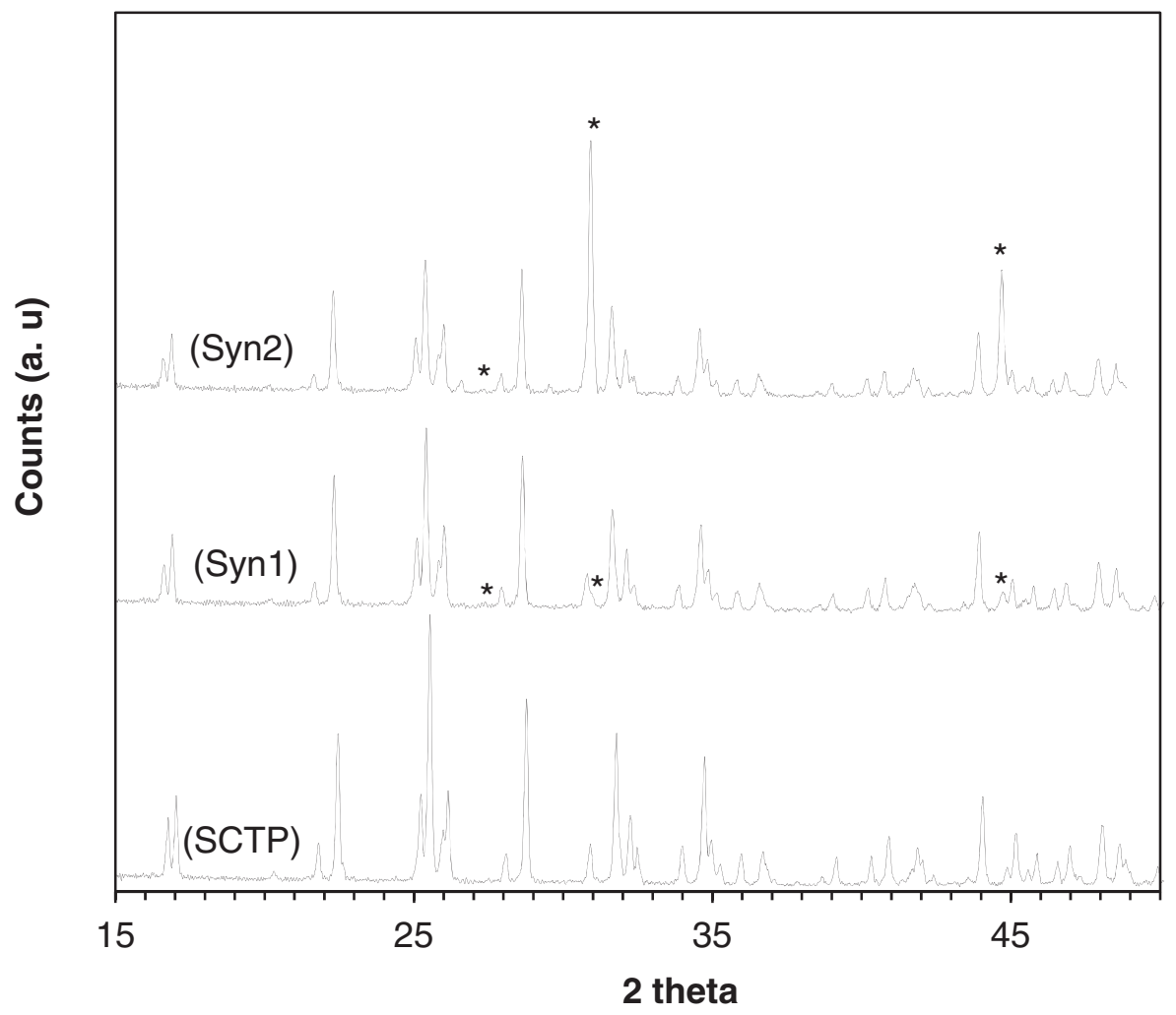

Figure 1 (SCTP): XRD pattern of pure SCTP. (Syn1): XRD pattern of the solid product formed at $600{ }^{\circ} \mathrm{C}$ and a $\mathrm{Na} / \mathrm{P}$ molar ratio of $1 / 1$ with $98 \%$ chloride elimination rate and $94 \%$ of selectivity for the $\mathrm{P}_{3} \mathrm{O}_{9}{ }^{3-}$ anion (Table 3 ). (Syn2): XRD pattern of the solid product formed at $400{ }^{\circ} \mathrm{C}$ and a $\mathrm{Na} / \mathrm{P}$ molar ratio of $2 / 1$ with $99 \%$ of selectivity for $\mathrm{P}_{3} \mathrm{O}_{9}{ }^{3-}$ anion (Table 4). (*): peak positions of the $\mathrm{NaCl}$ diffraction in $2 \theta$ range from 15 to $50^{\circ}$. 


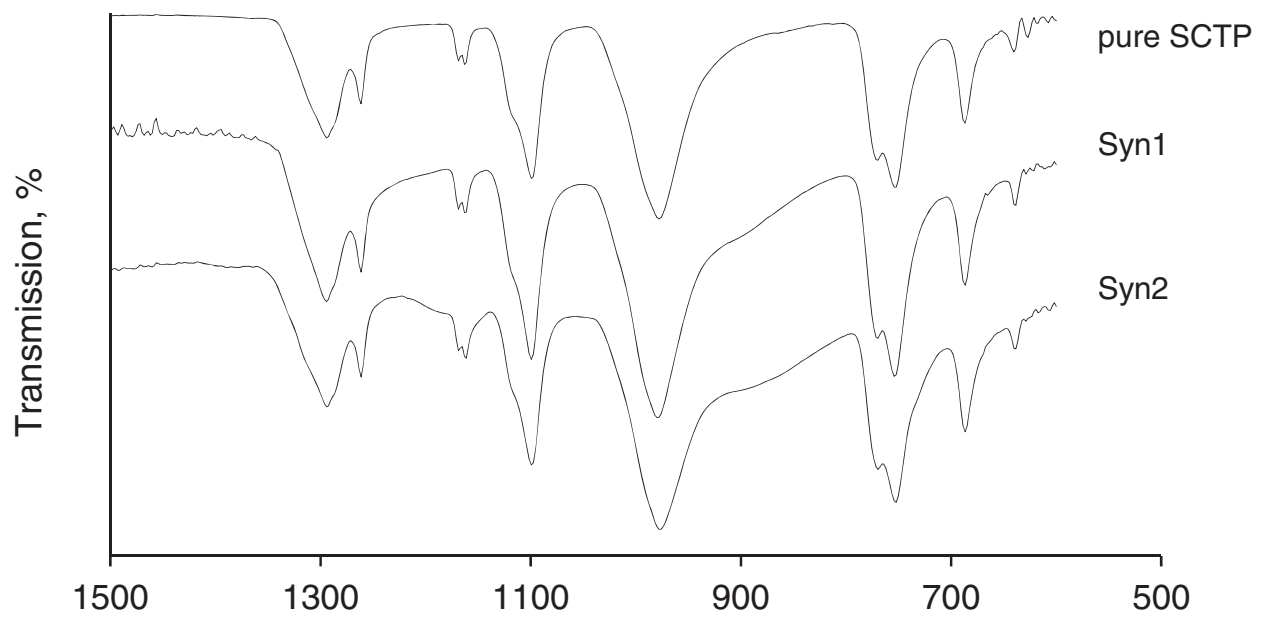

Wavenummber, $1 / \mathrm{cm}$

Figure 2 IR spectra of (STM): pure STM; (Syn1): solid product formed at $600{ }^{\circ} \mathrm{C}$ and a Na/P molar ratio of $1 / 1$ with $98 \%$ chloride elimination rate and $94 \%$ of selectivity for the $\mathrm{P}_{3} \mathrm{O}_{9}{ }^{3-}$ anion (Table 3); (Syn2): solid product formed at $400{ }^{\circ} \mathrm{C}$ and a Na/P molar ratio of $2 / 1$ with $99 \%$ of selectivity for the $\mathrm{P}_{3} \mathrm{O}_{9}{ }^{3-}$ anion (Table 4).

of pure SCTP. Both products, $\mathrm{Syn} 1$ and $\mathrm{Syn} 2$, did not contain $\mathrm{Na}_{2} \mathrm{HP}_{3} \mathrm{O}_{9}$ as byproduct. XRD patterns of the product Syn1 and pure SCTP are very similar. $\mathrm{NaCl}$ was practically not detected in Syn 1 according to the almost complete elimination of chlorine (98\%). For the product Syn2, all peaks could be attributed to SCTP and $\mathrm{NaCl}$. In fact, half of the $\mathrm{NaCl}$ remained in Syn 2 because of the excess of $\mathrm{NaCl}$ in the synthesis using the $\mathrm{Na} / \mathrm{P}$ molar ratio of 2/1.

IR Analysis. Figure 2 compares the IR spectra of pure SCTP with the spectra of the two solid products Syn1 and Syn2.

Both solid products synthesized showed IR spectra similar to that of pure SCTP, and display characteristic bands in the range of $650-1400 \mathrm{~cm}^{-1} \cdot{ }^{15-17}$ No other bands were observed in the range $1400-4000 \mathrm{~cm}^{-1}$. Note that the remaining $\mathrm{NaCl}$ does not show an IR signal. These results confirm again that the SCTP synthesized is well crystallized.

\section{CONCLUSIONS}

A new route for the direct synthesis of SCTP from sodium chloride and orthophosphoric acid as economical starting materials was developed. The reaction temperature, heating rate, air flow rate, reaction plateau time, and $\mathrm{Na} / \mathrm{P}$ molar ratio were found to be important parameters for the elimination of chloride and the selectivity with respect to SCTP. Complete elimination of chloride and high yield of SCTP could be obtained under the following conditions:

- Moderate heating rate of $5^{\circ} \mathrm{C} / \mathrm{min}$ and reaction temperature of $600{ }^{\circ} \mathrm{C}$.

- Air flow rate of at least $60 \mathrm{~L} / \mathrm{h}$ permitting an effective removal of the gaseous products.

- Reaction plateau time of about $120 \mathrm{~min}$.

- $\mathrm{Na} / \mathrm{P}$ molar ratio of $1 / 1$ or $2 / 1$.

Starting from a Na/P molar ratio of $1 / 1$, the best result was obtained with $98 \%$ of chloride elimination and $94 \%$ of selectivity for SCTP (reaction conditions: temperature of $600{ }^{\circ} \mathrm{C}$, heating rate of $5{ }^{\circ} \mathrm{C} / \mathrm{min}$, air flow rate of $120 \mathrm{~L} / \mathrm{h}$, and reaction plateau time of $120 \mathrm{~min}$ ). Increase of the molar ratio $\mathrm{Na} / \mathrm{P}$ to $2 / 1$ results in a complete transformation of the 
initial orthophosphoric acid into SCTP at only $400{ }^{\circ} \mathrm{C}$. A mixture of pure SCTP and $\mathrm{NaCl}$ was obtained. These results are technically and economically very interesting in comparison with the actual competing industrial process for the fabrication of SCTP. Hydrochloric acid was the only product in gas phase, which could be condensed and recovered in liquid form as pure chemical product.

Future investigations will focus on the purification of the solid product to obtain pure SCTP, for example, by recrystallization. The reactor engineering aspects of the process should be also considered, for example, a reactor equipped with a stirring system, for the improvement of the performance of the process.

\section{EXPERIMENTAL}

Fine powder of sodium chloride from Acros Organics (99.5\%) with a volume-mean diameter of $375 \mu \mathrm{m}$ and phosphoric acid (85 wt\% pure grade) from Merck were used as starting reactants. Pure SCTP (99\%) was purchased from Sigma-Aldrich. The experimental setup was described elsewhere. ${ }^{13}$ For the reaction, the quartz reactor was loaded with sodium chloride powder and $85 \mathrm{wt} \%$ orthophosphoric acid at room temperature. The reactor was then heated to the reaction temperature and kept at this temperature between $5 \mathrm{~min}$ and $24 \mathrm{~h}$. According to our previous work, all experiments were carried out at a temperature lower than $625^{\circ} \mathrm{C}$ to avoid the transformation of SCTP in glass amorphous products. ${ }^{13}$ After this plateau time, the reactor was freely cooled down to room temperature. During the reaction, an air circulation at constant flow rate was applied to remove the gaseous products formed. The gaseous products were trapped into a wash bottle containing an aqueous solution of potassium hydroxide.

The solid product was crushed into fine powder prior to all analyses and characterizations. ICP-AES (inductive coupled plasma atomic emission spectroscopy) analysis was carried out with a HORIBA Jobin Yvon Ultima 2 instrument for quantification of sodium and phosphorus. Chloride $\left(\mathrm{Cl}^{-}\right)$, orthophosphate $\left(\mathrm{PO}_{4}{ }^{3-}\right)$, pyrophosphate $\left(\mathrm{P}_{2} \mathrm{O}_{7}{ }^{4-}\right)$, and cyclotriphosphate $\left(\mathrm{P}_{3} \mathrm{O}_{9}{ }^{3-}\right)$ anions were analyzed with a Dionex ionic chromatography apparatus equipped with a Dionex IonPac AS $19(4 \times 250 \mathrm{~mm})$ column, a Dionex P/N 061830 conductivity detector, and a Dionex ICS-3000 EG eluant generator. Ultra-pure water was used as mobile phase, eluted at a rate of $1 \mathrm{~mL} / \mathrm{min}$.

From the results of ionic chromatography analysis, the selectivity for the $\mathrm{P}_{3} \mathrm{O}_{9}{ }^{3-}$ anion $\left(S_{\mathrm{P} 309}\right)$ was calculated as follows: $S_{\mathrm{P} 309}=100 \times n_{\mathrm{P}}{ }^{\mathrm{P} 309} / n_{\mathrm{P}}{ }^{\mathrm{i}}$ where $n_{\mathrm{P}}{ }^{\mathrm{P} 309}$ was the quantity (mole) of phosphorus converted in $\mathrm{P}_{3} \mathrm{O}_{9}{ }^{3-}$ anion and $\mathrm{n}_{\mathrm{P}}{ }^{\mathrm{i}}$ was the initial quantity (mole) of phosphorus introduced in the reactor.

IR (infra-red) spectra were measured with a Shimadzu FTIR 8400S spectrometer using a sensitive pyroelectric detector with an L-alanine-doped deuterated triglycine sulfate (DLATGS) element. Solid powder samples were directly measured in the wave number range 500-4000 $\mathrm{cm}^{-1}$. XRD (X-ray diffraction) measurements were carried out using a Phillips Panalytical X'pert Pro MPD diffractometer with a $\mathrm{Cu} \mathrm{K} \alpha(1.543 \AA$ A $)$ radiation source.

\section{REFERENCES}

1. Rashchi, F.; Finch, J. A. Miner. Eng. 2000, 13, 1019-1935.

2. Averbuch-Pouchot, M.-T.; Durif, A. Topics in Phosphate Chemistry; World Scientific: Singapore, 1996, pp. 31-36. 
3. Sidney, O.; Andrew, B.; Tom, C.; Robert, M. P.; Rita, K.; Marc, G. Mat. Res. Bull. 2008, 43, 68-80.

4. Onoda, H.; Nariai, H.; Moriwaki, A.; Maki, H.; Motooka, I. J. Mater. Chem. 2002, 12, 1754-1760.

5. Halliwell, D. J.; Mckelvie, I. D.; Hart, B. T.; Dunhill, R. H. Wat. Res. 2001, 35, 448-454.

6. Papo, A.; Piani, L.; Ricceri, R. Colloid Surface 2002, 201, 219-230.

7. Ferrer, J. C.; Salinas-Castillo, A.; Alonso, J. L.; Fernández de Ávila, S.; Mallavian, R. Mater. Lett. 2009, 63, 638-640.

8. Butt, F. H.; Bou-Hassan, A. H. Desalination 1981, 36, 129-136.

9. Averbuch-Pouchot, M.-T.; Durif, A. Topics in Phosphate Chemistry; World Scientific: Singapore, 1996, pp. 254-263.

10. Thilo, E. H.; Grunze, H. Z. Anorg. Allg. Chem. 1955, 281, 262-283.

11. Ondik, H. M. Acta Crystallogr 1965, 18, 226-232.

12. Durif, A. Solid State Sci. 2005, 7, 760-766.

13. Pham Minh, D.; Ramaroson, J.; Nzihou, A.; Sharrock, P.; Depelsenaire, G. Phosphorus, Sulfur, Silicon Relat. Elem. 2012, 187, 112-120.

14. Van Wazer, J. R. Phosphorus and Its Compounds, Volume I: Chemistry; Interscience Publishers: New York, 1958, p. 683.

15. Sbai, K.; Belaaouad, S.; Abouimrane, A.; Moutaabbid, M. Mat. Res. Bull. 2002, 37, 915-924.

16. Nahdi, K.; Ferid, M.; Trabelsi-Ayadi, M. Thermochim. Acta. 2009, 487, 54-59.

17. Jouini, A.; Ferid, M.; Gâcon, J. C.; Grosvalet, L.; Thozet, A.; Trabelsi-Ayadi, M. Mat. Res. Bull. 2006, 41, 1370- 1377. 